\title{
Philosophical reflections in sisupalavadhan: a brief discussion
}

\author{
Dr. Jhuma Chatterjee ${ }^{1} \&$ Mr. Arup Kumar Mondal ${ }^{2}$ \\ ${ }^{I}$ Assistant teacher in Sanskrit, Bolpur Sailabala Girls' High School,Bolpur, Birbhum, WB, India \\ ${ }^{2}$ Librarian, Bolpur Sailabala Girls' High School,Bolpur, Birbhum, WB, India
}

\begin{abstract}
Mahākavya deals with several Philosophical ideas. These are Vedānta-Mīmāminsā, sāmikhya-yaga, Nyāya-Vaiśesika. Mahakabi Māgha, the author of the novel 'Siśupālavadham' has given major emphasis on sāmkhya -yaga, Nyāya-Vaiśesika in his writings. This study proposed to make an attempt at comprehensively collecting and analysing the quotations and paraphrases from and allusions to the text of the Sāimkhya and Yoga.
\end{abstract}

Keywords: slaying, allusion, reflection, Orthodox, Hetrodox, Tattvasamasa.

\section{Introduction}

Māgha, the popular poet of $7^{\text {th }}$ century A.D. (approx) is well known for his only work 'Śiśupālavadham'. The Mahākavya 'Śiśupālavadham'consists of ' 20 ' cantos related to the episode in the Mahābharata of Kriṣna's slaying of Śiśupāla. It is seen from the Mahākavya 'Śiśupālavadham' that some philosophical allusions have been used here.

This study proposed to make an attempt at comprehensively collecting and analysing the quotations and paraphrases from and allusions to the text of the Sāmkhya and Yoga.

\section{About Indian Philosophical School Of Thought}

Indian philosophy broadly divided into two classes, namely Orthodox and Hetrodox. Orthodox school of thought has formed with six sub-systems. These are: Mīmāmsā, Vedānta, Sāmkhya, Yoga, Nyāya and Vaiśesika. They not only believe in God but also accept the authority of Vedas. That's why they are called Orthodox. On the other hand, a Hetrodox school of thought consists of Bauddha, Jaina and Cārvaka philosophy. They did not believe in God as well as reject the authority of Vedas. Present study has not concerned with Hetrodox school of thought, as the author Māgha rarely used Hetrodox School in his Mahākavya 'Siśupālavadham.' It is also seen from the Mahākavya that, the author used allusions in śloka taking from orthodox school. This paper mainly reflected the school of Sāmkhya and Yoga.

\section{Philosophical Reflection In Mahakavya(Epic)}

\subsection{Reflection of Sāmikhya Philosophy in 'Śiśupālavadham' Mahākavya}

Among all Indian philosophies sāmkhya is the oldest one. Its roots are in the Vedas. The great western philosopher Maxmullar refers Tattvasamāsa, Sāmkhya as oldest book. According to Maxmullar, 'Tattvasamasa' is the main source of Sāmkhya composed by 'Maharsi Kapila.'

In Māgha's Śiśupālavadham, Sāmkhya philosophy has influenced a great deal. Generally Sāmkhya philosophy has discussed four dharmas viz, Prakrti, Vikrti, Prakrti-Vikrti, Anubhaya i.e. neither Prakrti nor Vikrti. Prakrti is nothing but an ultimate cause of the world. It is always active. Vikāra or Vikrti are of sixteen types, including five organs of perception, five organs of action, mind (manas) and five physical elements (pañcamahābhuta). Mahat or Buddhi, Ahamkāra or ego and pañcatanmātra (five organs of knowledge) are the seven elements of Anubhaya. Anubhaya has its own entity; as a result it does not come under Prakrti and Vikrti. Forth type of characteristic is Anubhaya, i.e. self.

Sāmkhya's philosophical doctrine 'Anubhaya' was reflected in Śiśupālavadham (1/33 śloka) as-

"Udāsitāram nigrihītamānasairgrihītamadhyātmadṛsā kathañcana

Bahirbikāram pṛkriteh pṛthagbiduh purātanamitvam puruṣam purābidah" (1/33 śloka)

Explanation: "The yogins arrested their mind and see themselves in the light of knowledge. Lord Sri Krisna is often indifferent from all aspects. The great poet Magha has described Lord Sri Krisna as indifferent i.e. he is different from Prakriti and Vikrti and considered Him as unchangeable self."

In the concerned verse Śrikriṣna is described as free from all gunas. Here Śrikrișna is compared to Anubhaya or self. He is neither prakrti nor vikrti. 


\subsection{Reflection of Yoga philosophy in 'Śiśupālavadham' Mahākavya}

Maharsi Patanjali is the founder of the Yoga Philosophy. He narrated 'God as a Special Being' in his 'Yoga-Sutra.' He also told about 'God' that, he is pure, Sattva-Chaitanya. God is different from normal being and soul, because he is not bonded with unholy alliance. General being suffers from Pañcakleśa. This being perform different Sorts of work and gets good or bad, Pāpa-Punya result. Due to special being other vices cannot touch God. He is free from all sorts of vices, works, effects, desires. He is immortal, bondless, complete and above all the beings.

Magha treated, 'God as special being' which was reflected in Śiśupālavadham (14/62 śloka) as:

"Sarbabedinamanādimāthitam dehināmanujighrikșyā bapuh

Kleśakarmaphalavogabargitam pumbiśeșammumīśvram biduh" (14/62 śloka)

Explanation: "The great poet Māgha compared Śrikrișna with God which is referred to, in Yoga philosophy. The God referred to, in Yoga philosophy as the ultimate knowledgeable being and immortal. He has come in the form of human being just to allow the living being of this world to be blessed by him. Lord Krișna is above all sorts of evil knowledge (Avidyā, Asmitā Rāga (anger) etc). He does not suffer from holy and unholy effect i.e. he is above all these things, he is God, The ultimate being or self. He cannot be compared with any other general human being unlike others. He does not get entangled into the materialistic world. So all the knowledgeable persons have accepted acknowledged Śrikrișṇa as God". (Śiśu-14/62)

It is also seen that, in Yoga philosophy Yama, Niyama, Dhyāna, Dhārana and Samādhi are referred to as different part of Yoga. In this philosophy Ahimsa, Sattva, Asteyo, Brahmacarya, Aparigraya are referred to as Yama. Ahimsa is non- violence against anything for all time. Sattvya is to be perfect in speech and mind. Thus Sattva is that expression when people think and say alike. Taking things of somebody in an unethical manner is known as Steya. Asteya is opposite to Steya. Brahmacarya is the control over private organ 'Upastha'. Aparigriha is self restraining by meditation. Niyama is Souca (purity), Somtosa (satisfaction), Tapas (meditation), Svadhyaya (To read the sastra of moksa) and Iswarapranidhana (emancipation i.e. all works to paramguru).

Mahākavi Māgha has referred to the part of Yoga like Yama and Niyama in his epic- Śiśu (13/23) as:

"Baṇinaṁkṣiterayanayābibeśvaraminiyama Yamacaniyatam Yatim Yathā

Bijayaśriyā britamibārkamārutābanusașrstustamathadașryoh sutou" (13/23 śloka)

Explanation: "It has been narrated in the sloka that, the great emperor is followed by providence and prowess, Yati is followed by Yama and Niyama, The triumphant king is followed by sun and wind, similarly Sri Krisna is followed by the sons of Asvidvya Nakula and Sahadeva.

\section{Conclusion}

Mahākabi Māgha was not only a great poet but also a great philosopher. His philosophical thinking was reflected in Siśupālavadham Mahākavya. The epic written by him was enriched with many valuable philosophical thoughts. Some of his philosophical thought which he has reflected in the epic of Mahākavya has specified in this study. It is very difficult to capture or search entire epic by oneself. It requires more and more research on same type study.

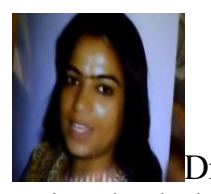

\section{Acknowledgements} national scholarship in the same year. She has completed her MA in Sanskrit from Viswa-Bharuti University in 2002. Dr. Chatterjee also completed B.Ed degree in 2003. She has completed Ph. D in 2010 from ViswaBharuti University. Presently she worked as Assistant Teacher in BOLPUR SAILABALA GIRLS' HIGH SCHOOL

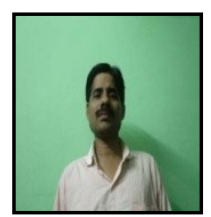

Sri Arup Kumar Mondal is a Librarian of Bolpur Sailabala Girls High School, Bolpur, in West Bengal. He has more than five years' experience as an assistant librarian in college. He obtained his MBA in 2001. He was awarded university gold medal by the University of Burdwan for the first rank in MLIS in 2005. He completed his M.Phil degree in LIS in 2008 from Burdwan University. Now he is engaged in doing Ph.D. from Burdwan University. He published seven papers in national \& international journals. 


\section{References}

[1]. J. Chatterjee, Philosophical allusions in the Kiratarjuniyam Sisupalavadham And Naisadhacaritam, doctoral diss., Viswa-Bharati University, Bolpur, W.B., India, 2011

[2]. A. Sengupta, Essays on Samkhya and other systems of Indian philosophy (Kanpur: Moti Mahal, 1964)

[3]. S. Chatterjee and D.M. Datta, (An) Introduction to Indian Philosophy (Kolkata: University of Calcutta, 1968). 